\title{
Segment Disclosure Quality and Relevance under IFRS Vs. U.S. GAAP
}

\author{
Jagjit S. Saini ${ }^{1}$ and Gaurav Kumar ${ }^{2}$ \\ ${ }^{1}$ Western Michigan University, ${ }^{2}$ University of Arkansas Little Rock
}

\begin{abstract}
Both IFRS (IFRS 8) and the United States (U.S.) GAAP (SFAS 131) use similar approach for reporting segment information as a part of annual financial statements. Large and multinational firms that operate in more than one operating segment are required by IFRS and the U.S. GAAP to provide financial information about their operating segments in the notes to the annual financial statements using the "management approach." However, the primary difference between these two pronouncements is how the management approach is implemented. Using a sample of foreign companies cross listed on the U.S. stock exchanges, we test for differences in segment financial reporting under the two sets of financial standards and how this information is valued by the market. We find significant differences in the quality and quantity of segment disclosure made by our sample firms during the fiscal year 2017 under the two sets of accounting standards. We also find that market values the choice of accounting standards as well as the overall quality/quantity of the segment disclosures. Specifically, we find that the decrease in the informativeness of earnings with IFRS as the choice of accounting standards for our sample firms. Additionally, we also find that the predictability and informativeness of earnings is increasing in the quality/quantity of the segment disclosure of the sample firm.
\end{abstract}

Keywords: segment disclosure, management approach, earnings informativeness

\section{Introduction and Motivation}

We compare the segment disclosures of foreign firms listed in the United States (U.S.) and contrast the value relevance of segment disclosures reported under U.S. GAAP and IFRS. The issuance of International Financial Reporting Standard (IFRS) 8 responds to the short-term convergence projects and the Memorandum of Understanding (MoU) between the International Journal of Accounting \& Business Finance 68 International Accounting Standards Board (IASB) and the Financial Accounting Standards Board (FASB). Prior to issuance of IFRS 8, IAS 14 governed the segment disclosures and required that segment information is disclosed by line of business and geographic segments. IFRS 8 represents a significant modification in segment reporting and requires firms to report disaggregated information about reportable Vol.6.No.1 2020 
segments based on the way management organizes the firm internally for the purpose of making operating decisions and assessing performance (Farias \& Rodriguez, 2015).

Segment disclosures provide a useful picture of the risk profile and growth opportunities for a firm. Analysts and institutional investors find this information important for decision-making. In response to user requests, SFAS 131, Disclosures about Segments of an Enterprise and Related information was issued in 1997 and became effective for fiscal years beginning after December 15, 1997. SFAS 131 requires that operating segments are reported based on the "management approach." IFRS 8 also adopted the management approach and was based closely on SFAS 131 (Nichols, Street, \& Tarca, 2013). However, the primary difference between IFRS 8 and SFAS 131 is in how the management approach is implemented. The "management approach" argues that firms organize and provide segment information in their financial reports based on the approach management organizes the firm internally for the purpose of decision making and performance evaluation. Thus, segment reporting standards under IFRS 8 and SFAS 131 of U.S.GAAP are similar in approach but argument is that the two are different in application of the management approach. Accordingly, as per IFRS 8, some segment disclosures are only required if included in measure of segment profit/loss reviewed by Chief Operating Decision Maker (CODM). Examples include capital expenditures, depreciation/amortization, equity method investment and income and other important items. Therefore, critics of IFRS 8 argued against movement to the pure management approach, allowing the reporting of nonIFRS segment measures, a potential decrease in geographic segment disclosures, and elimination of the requirement to disclose segment liabilities (Crawford, Extance, Hellier, \& Power, 2012).

Nichols et al. (2013) suggest that more research is needed to determine whether the increase in IFRS 8 country-specific information is useful to investors and other users and whether the loss of some disclosures is detrimental to users. Therefore, we compare the value relevance of segment disclosures provided by all foreign companies listed in the U.S. These foreign companies listed in the U.S. provide an excellent opportunity to compare segment reporting under SFAS 131 and IFRS 8 because since 2008 such companies have an option to use the U.S. GAAP or IFRS for financial reporting with SEC in the U.S. As a result if a foreign company listed in the U.S. is already using IFRS for financial reporting in their home country then they are no longer required to reconcile to the U.S. GAAP if they chose to do so. Using a sample of these foreign firms listed in the U.S. we compare the segment financial reporting under the U.S. GAAP (SFAS 131) and IFRS (IFRS 8).

According to International Accounting Standards Board [IASB] (2013), one of the anticipated benefits from the application of IFRS 8 is that investors will be able to see the business through management's eyes and be able to predict the future cash flows more reliably. This paper compares the segment disclosure provided by the U.S.- listed foreign companies that are using IFRS vs. such companies that are using U.S. GAAP for financial reporting. We find significant 
differences in segment reporting by the U.S. listed foreign firms under the two sets of accounting standards and that these two factors - choice of accounting standard and the quality/quantity of segment information, affect how market evaluates the firm. The next section reviews the literature and develops our hypotheses for this study. In section 3, we discuss our sample selection and data for our study. Section 4 presents our methodology and discussion of the results of our hypotheses testing. Finally, section 5 concludes this paper and provides limitation of this study.

\section{Literature Review and Hypotheses}

Various studies have shown that significant managerial discretion exists in segment disclosures provided by different companies. Even though IASB and FASB have been working together to enhance the comparability of financial statements, there is still substantial variation in segment disclosures. For example, Kobbi-Fakhfakh, Shabou, and Pige (2018) test the segment disclosures for a sample of $171 \mathrm{EU}$ companies from the 2006-2012 annual reports and report that there are significant differences in the quality of segment reporting among the sampled firms. They construct a new measure of segment reporting quality (SRQI) that aggregate different segment reporting practices indicators, including the number of segments, the extent of information disclosed and the geographic disclosures. They find that large corporations that are audited by Big 4 auditors and more internally oriented, tend to provide a higher quality of segment reporting. On the other hand, they report that firms with debt leverage provide lesser quality segment disclosures.
Prior research has shown that there is some leeway for companies with regard to segment disclosures. There are two main components of segment disclosures: information provided for each segment and the number of operating segments disclosed. The standard requires the disclosure of a segment and related items if the management reviews them regularly. Andre, Filip, and Moldovan (2016) argue that this condition introduces a voluntary component to segment line-item disclosure since management can use it as a pretext to avoid certain segment-level line items. On the other hand, some companies could strictly follow the standard and disclose only the line items suggested even though the management reviews more items than that. Finally, some firms could disclose many other line items that are not suggested by the official pronouncement. Either way, all these companies are technically within the requirements of the standard. This variability has been well documented in the literature. For example, Nichols et al. (2013) report that IFRS has led to an increase in the number of operating segments on average for a sample of European blue chip companies. Crawford et al. (2012) find that the number of line items disclosed per segment is, on average, lower under IFRS 8 than under IAS 14R, most likely due to the fact that IFRS 8 requires that items shall be disclosed if they are reported to management.

We compare the segment disclosures of the U.S. listed foreign companies that use U.S. GAAP with the ones that use IFRS. SFAS 131 was issued in 1997 by the FASB and it was considered pretty unique at the time since it was the first standard that was 
specifically targeted to address financial analysts' concerns that the previous standard (SFAS 14) allowed managers too much flexibility (Botosan \& Stanford, 2005). SFAS 131 requires that reportable segments be determined based on the "management approach." That means that segment disclosures should be provided following a company's organizational chart and reflective of the positions/units that report directly to the Chief Operating Decision Maker (CODM) (Nichols et al., 2013). Many studies have found that SFAS 131 has resulted into an increase in the number of segments and segment information reported by firms and that has improved the market's ability to predict future earnings (Ettredge, Kwon, Smith \& Zarowin, 2005; Hope, Kang, Thomas \& Vasvari, 2009).

IFRS 8, issued in 2006, adopted the "pure management approach", which is mostly similar to SFAS 131, requires some segment disclosures, only if, they are included in the measure of segment profit/loss reviewed by CODM. Another difference is that IFRS 8, unlike SFAS 131 requires disclosure of segment liabilities if those amounts are regularly reviewed by the CODM (Nichols et al., 2013).

\subsection{Hypotheses Development}

The IASB states that academic research indicates the application of SFAS 131 resulted in more useful information than its predecessor SFAS 14 (IFRS 8, BC 6). According to the research, the SFAS 131 management approach:

- Increased the number of reportable operating segments and provided more information per operating segment.

- Enabled users to see an entity through the eyes of management.
- Enabled an entity to provide timely segment information for external interim reporting with relatively low incremental cost.

Other studies, such as Hermann and Thomas (2000); Street, Nichols, and Gray (2000); and Berger and Hann (2003) also supported these findings. However, IFRS 8 only requires companies to provide segment disclosure if they are reviewed by the CODM. So, we argue that segment disclosure will be less detailed under IFRS as compared to U.S. GAAP. Therefore, our first two hypotheses are stated as follows:

H1: The number of segments reported will be less in IFRS reporting companies as compared to U.S. GAAP companies.

H2: IFRS firms will have less number of words in their segment disclosure as compared to U.S. GAAP companies.

H3: Number of items disclosed under IFRS will be less than number of items disclosed under U.S. GAAP

H4: Segment disclosure quality under U.S. GAAP will be superior to segment disclosure quality under IFRS.

Since, we hypothesize that segment disclosure under the U.S.GAAP are superior to segment disclosure under IFRS, we further hypothesize that:

H5: Foreign firms reporting segment disclosure under the U.S. GAAP earn better returns on U.S. stock exchanges than firms using IFRS.

Another line of research suggests that managers have more incentives to obfuscate information when firm performance is bad (Bloomfield, 2002). Consistent with this obfuscation hypothesis, Li (2008) investigates a sample of more than 50,000 
firm-years and finds that firms with lower earnings tend to file annual reports that are more difficult to read. $\mathrm{Li}$ (2008) reports that an increase in earnings from the previous year also results in annual reports that are easier to read compared to previous year's reports and vice-versa. A corollary to these results is that when a company has a loss, their segment disclosures will be less readable, lengthy and complex. Therefore, we frame the following hypotheses.

H6: The word-count in loss firms will be higher in firms reporting a loss as compared to firms reporting a profit irrespective of whether the firms are using IFRS or U.S. GAAP.

Finally, prior studies have found a significant association between returns and changes in current and future earnings of the firm (see e.g. Collins, Kothari, Shanken, \& Sloan, 1994; Lundholm \& Myers, 2002). Based on these studies, Ettredge et al. (2005) investigate the effect of segment disclosure rules on the stock market's ability to predict the firms' earnings. They refer to this as stock price informativeness as measured by the forward earnings response coefficient (FERC) based on the returns-earnings association. They report that pre-131 multisegment firms experienced a significant increase in FERC after adopting SFAS No. 131 , regardless of whether they increased their number of reported business segments. Therefore, we expect higher quality and quantity of segment disclosure under both U.S. GAAP and IFRS will improve the informativeness of the earnings. We expect that earnings response coefficients (ERCs) will increase under both IFRS 8 and SFAS 131. Therefore, we frame the following hypotheses:
H7: Earnings Response Coefficients will be similar under IFRS and U.S. GAAP.

H8: Earnings Response Coefficient will be better for firms with higher quality/quantity segment disclosures.

\section{Sample and Data}

We select our sample for the study from the CRSP/COMPUSTAT merged database available through CRSP-SIFT interface. Our sample includes all foreign firms (companies incorporated outside the USA) listed on NYSE, NYSE Market, ARCA, and NASDAQ stock exchanges as an ordinary share or ADR. We only include data for the fiscal year 2017 and the firms with December fiscal year end. We also require our sample firm to have both - the country of incorporation (Compustat item 'FIC') outside the USA and location of headquarters (Compustat item 'LOC') outside the USA. We delete the firm with any a merger/acquisition activity during the period and only keep the firm with "unqualified" opinion from the independent auditors. As a result we have a total of 155 firms in our sample that includes 77 firms using US-GAAP and 78 firms using IFRS for financial reporting. We delete 44 firms that do not provide any segment disclosure or had missing financial data on SEC Edgar database. We also delete 3 more firms in utility (SIC 4900-4999) or financial (SIC 6000-6999) industries. We further delete 18 firms with missing earnings and returns data on Compustat and CRSP. As a result we end up with a final sample of 90 firms. Our sample selection process is documented in Table 1. 


\section{INSERT TABLE 1 HERE}

\subsection{Descriptive statistics and variable definitions}

Table 2 shows descriptive statistics of our sample firms. Our sample firms earn a mean return of -0.0159 . In our sample $56.67 \%$ firms use IFRS for financial reporting. On an average our sample firms report 3.1222 operating segments and segment disclosure include about 626 words on an average. Also, the average number of words reported per segment is about 225 words for our sample firm. An average sample firm reports 10.6222 items in disclosure note for segment information. We also develop a segment disclosure index (SDINDEX) as a measure of segment disclosure quality based on the hand collected segment data. Maximum possible value of index is 2 and our average sample firm has a SDINDEX of 1.2699.

\section{INSERT TABLE 2 HERE}

All the variables used in this study are defined in Exhibit 1. Also, we describe the development of our segment disclosure index, SDINDEX, in Appendix A.

\subsection{Correlations}

Table 3 reports Pearson and Spearman correlations between our variables of interest in this study. Our discussion here is based on Pearson correlations. However, the results are similar under Spearman correlations. We find a significant negative and high correlation (-0.2372) between returns $\left(R_{t}\right)$ and $I F R S$ indicating that sample firms using IFRS earned negative returns compared to firms using the U.S.GAAP. Also, we find a significant positive correlation of 0.2312 between returns $\left(R_{t}\right)$ and $S D Q T Y$ indicating that firms who report extensive segment disclosure earn higher returns. There is a significant high positive correlation (0.3679) between IFRS and NUMSEG indicating that sample firms using IFRS reporter higher number of operating segments as compared to sample firms using U.S. GAAP. Also, there is a significant positive correlation between IFRS and NUMITEMS indicating that sample firms using IFRS reported more number of items while disclosing segment information in the notes as compared to firms using U.S. GAAP. There is a significant negative correlation between IFRS and quantity of segment disclosure (as measured by WORDSPERSEG and SDQTY) indicating that sample firms using IFRS had less detailed segment information disclosed in the notes than the sample firms using U.S. GAAP. We also find that our measure of quality of segment information, SDINDEX, is significantly correlated to NUMSEG and NUMITEMS indicating the firms reporting more number of segments and more number of items scored higher in our segment disclosure index.

\section{INSERT TABLE 3 HERE}

\section{Methodology and results}

We use univariate parametric and nonparametric tests of difference in means (medians) to test our hypotheses H1-H6. Specifically we use $t$-test of significance of difference in means (parametric test). Additionally we also report the results of Kruskal-Wallis test of difference in medians (non-parametric test) because our sample size is small. Results of univariate tests are reported in Table 4 and 5. Our discussion below is based on parametric $t$-tests but results of non-parametric tests are no different. 
Mean number of segments reported by firms using U.S. GAAP was 2.0769 compared to 3.9216 for the firms using IFRS. The difference of 1.8446 is significant at $1 \%$ level. From this we can conclude that IFRS firms reported more number of segments on an average compared to U.S. GAAP firms. Therefore, we reject our first hypothesis that number of segments reported will be more under the U.S. GAAP. On the contrary, we find that foreign firms using IFRS reported more number of segments on an average. Next we test if number of words in segment disclosure were different under the two GAAPs. We use three different measures to test this hypothesis. Our first measure is the actual number of words (NUMWORDS) disclosed under the note "Segment information" by the sample firm. However, we would expect the number of words to be more for the firms operating in multiple segments compared to single segment firms or firms with lesser number of segments. Therefore, our second measure is a scaled measure. We measure number of words reported by the sample firms per segment (WORDSPERSEG). Our third measure is the logarithmic transformation of number of words reported per segment (SDQTY). The total number of word reported on an average under segment disclosure was greater for the firms using IFRS as compared to U.S. GAAP firms but this difference in means was not significantly different. However, the number of words disclosed per segment (WORDSPERSEG) was significantly higher for firms using U.S. GAAP $($ mean $=279.4)$ compared to firms using IFRS (mean = 183). Also, average value of $S D Q T Y$ was 5.4520 for firms using U.S.GAAP compared to a value of 4.8572 for firms using IFRS. The difference in means is significant at $1 \%$ level. From this we can conclude that firms using U.S.GAAP disclosed more number of words in segment information compared to their counterparts using IFRS. Hence, we reject our $\mathrm{H} 2$ and conclude that the quantity of segment disclosure is lesser for firms using IFRS compared to firms using the U.S. GAAP for financial reporting. Mean number of items (NUMITEMS) reported under segment disclosure by the firms using IFRS was significantly greater than the firms using the U.S.GAAP. The mean difference of 5.5324 is significant at $5 \%$ level of significance. We reject our hypothesis 3 that firms using IFRS disclose lesser number of items under segment disclosure. We further reject our next hypothesis, $H 4$, that segment disclosure quality of firms using the U.S.GAAP is superior to segment disclosure quality of firms using IFRS. We don't find any significant difference in mean SDINDEX for both group of sample firms. $S D I N D E X$ for firms using IFRS was slightly higher but not significantly different from SDINDEX of firms using the U.S.GAAP. However, we find that firms using the U.S.GAAP earned significantly better returns than the firms using IFRS confirming our hypothesis 5 .

\section{INSERT TABLE 4 HERE}

We further conduct the univariate test of difference in means for the firms incurring losses vs. the profitable firms to test hypothesis 6 . Results of these tests are reported in Table 5. We find that firms incurring losses reported significantly lesser number of words (WORDS) than the profitable firms under the segment disclosure. Also, the number of words per segment ( $W O R D P E R S E G$ ) was significantly lesser for loss firms as compared to profitable firms. Loss firms also 
reported significantly lesser number of items than the profitable firms. We, therefore, reject our hypothesis 6 that word count of segment disclosure of loss firms is more compared to profitable firms.

\section{INSERT TABLE 5 HERE}

To test hypotheses 7 and 8 we use multivariate regression model based on prior studies on earnings response coefficients (see, for example, Collins et. al (1994); Lundholm and Myers (2002); Ettredge et. al (2005); Saini et. al (2017)). Specifically, we use following regression model:

Where, $R_{t}$ is annual stock return measured over the period beginning nine months prior to the fiscal year end and ending three months after the fiscal year end. $E_{t-1}, E_{t}$, and $E_{t+1}$ represent scaled earnings available to common shareholders during prior period, current period, and realized next period. Coefficients on $E_{t-1}, E_{p}$ and $E_{t+1}$ are called the earnings response coefficients (ERCs) on past, current, and future earnings. Results of this regression model are reported in Table 6. Column 1 reports regression of past, current, and future earnings on the returns and results are consistent with prior research. ERC is negative on past earnings and ERCs are significantly positive on current and future earnings. In column 3 , we include dummy variable, IFRS, and our measure of segment disclosure quality, SDINDEX along with industry dummies based on two-digit SIC codes. We don't find any significance on either IFRS or $S D I N D E X$. Next we test for mediation effect of accounting standards (IFRS vs. U.S.GAAP) and segment disclosure quality on the ERCs. Results of our full model are reported in column 6 of table 6 . We find a significant negative coefficient (-8.4730) on the interaction of IFRS and future earnings, $E_{t+1}$ indicating that informativeness of future earnings is decreasing in use of IFRS as a choice of accounting standards for our sample firms. However, this negative effect is alleviated by higher quality segment disclosure as we find a significant positive coefficient (5.8327) on the three-way interaction of IFRS, $E_{t+1}$, and SDINDEX.

INSERT TABLE 6 HERE

We also run our regression in above equation (1) above by replacing SDINDEX with our measure of segment disclosure quantity, $S D Q T Y$. Results of this regression are reported in table 7 . Our results in this regression are similar. We find that informativeness of future earnings is significantly decreasing in use of IFRS as the choice of accounting standards as evident from significant negative coefficient of -8.1360 on the interaction of IFRS and $E_{t+1}$. We also, find a significant positive coefficient of 1.4609 on the interaction of IFRS, SDQTY, and $E_{t+1}$ indicating that the decrease in informativeness of future earnings by use of IFRS is alleviated by higher quantity of segment disclosure as measured by SDQTY based on the word count per segment. We observe a similar result for the ERC on current earnings as well. ERC on current earning is also decreasing in the use of IFRS but higher quantity of segment disclosure alleviates this decrease in informativeness of current earnings.

\section{INSERT TABLE 7}

\subsection{Additional Test}

In additional test, we control for the size, growth, profitability, and audit quality of the sample firm. These variables have been found to be associated with the returns 
of the firm. We include these variables in our regression equation (1). SIZE is measured as the market capitalization of the sample firm at the beginning of the year. Bigger firms have been found to earn better returns. Growth is measured as the logarithmic transformation of the ratio of market value to the book value of the stock (MKT2BOOK). We expect that high growth firms earn better returns compared to slow growth firms. Profitability also affects the returns of the firm. Profitable firms earn better returns compared to firms incurring losses. We control for profitability using a dummy variable, LOSS which has a value equal to 1 if firm incurred loss during current year. We control for audit quality using a dummy variable, BIGNAUDITOR which has a value equal to 1 if sample firm had a Big Four auditor during the fiscal year. After controlling for these variables our results are consistent with our main results. ERC of future earnings is decreasing in IFRS as indicated by significant negative coefficient of -6.8032. But this decrease in ERC is alleviated by quality of segment disclosure as evident from significant positive coefficient of 4.9376 on the three-way interaction of IFRS, SDINDEX, and $E_{t+1}$. Results of this regression are reported in table 8 .

\section{INSERT TABLE 8 HERE}

\section{Conclusion}

IFRS switched to use of "management approach" for disclosing segment information in the notes to the financial statements. Segment information provides valuable insights to the market participants in evaluating the operations of large and multinational firms. Segment information provides details of the operations for different business segments, product segments, geographical segments, and other operational segments of the firm. The "management approach" argues that firms organize and provide segment information in their financial reports based on the approach management organizes the firm internally for the purpose of decision making and performance evaluation. Thus, segment reporting standards under IFRS 8 and SFAS 131 of U.S.GAAP are similar in approach but argument is that the two are different in application of the management approach. Foreign firms listed in the U.S. provide an excellent opportunity to compare the segment reporting under the two sets of accounting standards because they have a choice to use either IFRS or the U.S.GAAP when filing their financial statements (using form 20-F) with SEC. We conduct univariate tests to compare the quantity and quality of the segment reporting under the two sets of accounting standards and find significant differences. Specifically, we find that our sample firms using IFRS reported more number of operating segments as compared to operating segments reported by sample firms using the U.S.GAAP. However, firms using U.S.GAAP provided more detailed segment information per segment as measured by word-count per segment in contrast to their counterparts using IFRS. From this we conclude that quantity of disclosure per segment was greater for firms using the U.S.GAAP. We also find that the firms using IFRS 8 reported more number of financial items under segment information as compared to the firms using the U.S.GAAP. To compare the quality of segment disclosure we develop a segment disclosure index (SDINDEX) and perform the univariate test of difference in means. We find that segment disclosure quality was slightly better under IFRS but the difference was not statistically 
significant. From this we can conclude that segment disclosure quality is comparable under the two sets of accounting standards. We further test for the effect of segment disclosure under IFRS 8 vs. SFAS 131 on the informativeness of earnings as measured by the ERCs in a returns-earnings regression. We find that ERCs are decreasing in the use of IFRS but additionally we also find that the decrease in ERCs is alleviated by superior quality and quantity of segment disclosure of the sample firm. These results are consistent with Ettredge et al. (2005) indicating that the predictability of future earnings (as measured by future ERC) is increasing in the quality and quantity of segment disclosure. From these results we can conclude that investors and market participants in the U.S. consider financial information provided under the U.S. GAAP to be superior to the financial information provided under the IFRS and that the quality and quantity of segment disclosure help improve the informativeness of earnings and predictability of the future earnings.

There are few limitations of our study. One, our sample size is quite small but it is large enough for conducting parametric tests of significance. Second limitation of this study is that our data is based on only one fiscal year, 2017 instead of multiple fiscal years. One reason, our sample size is small and we only include data from one fiscal year is because we rely on hand collected data which would be hard to do on a large sample over multiple years. Another reason is that we are only looking at the sample of foreign firms listed in the U.S. that file annual financial statements with SEC. The number of such firms is small. In future, this study can be extended over multiple fiscal years to more insights into the segment reporting under the two sets of accounting standards. Another interesting study for future would be to compare the segment reporting of the U.S.-listed foreign firms with domestic U.S. firms (registered in the U.S.). This would offer two comparisons. One, the comparison of cross listed foreign firm using IFRS 8 against a domestic U.S. firm and two, the comparison of cross listed foreign firm using SFAS 131 against a domestic U.S. firm.

Overall, our results show significant differences in segment reporting by the U.S. listed foreign firms under the two sets of accounting standards and that these two factors - choice of accounting standard and the quality/quantity of segment information, affect how market evaluates the firm.

This study contributes in to current literature in several ways. It helps our understanding of knowing the differences in the segment reporting by firms listed in the U.S. under the two sets of available accounting standards (IFRS 8 and SFAS 131). It also contributes in comparing the quality and quantity of segment disclosure under the two sets of accounting standards. This study further contributes in understanding the importance of choice of accounting standards and understanding the effect of quality and/or quantity of segment disclosure on the valuation of the stock by the market participants. Consistent with prior literature, we observe that segment disclosure improve the informativeness and predictability of earnings.

\section{References}

Andre, P., Filip, A. \& Moldovan, R. (2016). Segment disclosure quantity and quality under IFRS 8: Determinants and the effect on financial analysts' earnings forecast errors. The International Journal of Accounting, 51(4), 443-461. 
Bloomfield, R.J. (2002). The "Incomplete revelation hypothesis" and financial reporting. Accounting Horizons, 16(3), 233-243.

Botosan, C. \& Stanford, M. (2005). Managers' motive to withhold segment disclosures and the effect of SFAS No. 131 on analysts' information environment. The Accounting Review, 80(3), 751-771.

Collins, D., Kothari, S., Shanken, J. \& Sloan, R. (1994). The lack of timeliness and noise as explanations for the low contemporaneous returns-earnings association. Journal of Accounting and Economics, 18(3), 289-324.

Crawford, L., Extance, H., Hellier, C. \& Power, D. (2012). Operating Segments: The useful segments of IFRS. Edinburgh, Scotland: ICAS Insight, the Institute of Chartered Accountants.

Ettredge, M.L., Kwon, S. Y., Smith, D.B., \& Zarowin, P.A. (2005). The impact of SFAS No. 131 business segment data on the market's ability to anticipate future earnings. The Accounting Review, 80(3), 777-804.

Farias, P. \& Rodriguez, R. (2015). Segment disclosures under IFRS 8's management approach: has segment reporting improved? Spanish Journal of Finance and Accounting, 44(2), 117-133.

Hope, O.-K, Kang, T., Thomas, W.B., \& Vasvari, F. (2009). The effects of SFAS 131 geographic segment disclosures by US multinational companies on the valuation of foreign earnings. Journal of International Business Studies, 40(3), 421-443.

IASB. (2013). Post-implementation Review of IFRS 8 Operating Segments. Review of Academic Literature to December 2012. Staff Paper 6B, IASB Board meeting January.

Kobbi-Fakhfakh, S., Shabou, R.M., \& Pige, B. (2018). Determinants of segment reporting quality: evidence from EU. Journal of Financial Reporting and Accounting, 16(1), 84-107.

Li, F. (2008). Annual report readability, current earnings, and earnings persistence. Journal of Accounting and Economics. 45(2-3), 221-247.

Lundholm, R. \& Myers, L. (2002). Bringing the future forward: the effect of disclosure on the returns-earnings relation. Journal of Accounting Research.40(3), 809-839.

Nichols, N.B., Street, D.L., \& Tarca. A. (2013). The impact of segment reporting under the IFRS 8 and SFAS 131 Management Approach: A research review. Journal of International Financial Management and Accounting, 24(3), 261312.

Saini, J., Arugaslan, O., \& DeMello, J. (2017). What values more? Agency costs or accrual quality. Journal of Financial Reporting and Accounting, 15(1), 22-38.

Street, D.L., Nichols, N.B., \& Gray, S.J. (2000). Segment disclosures under SFAS No. 131: Has Business Segment Reporting improved? Accounting Horizons, 14(3), 259-285. 
TABLE 1: Sample Selection

\begin{tabular}{lc}
\hline Sample selection criteria & \# of firms \\
\hline All foreign firms (with country of incorporation, data "FIC," and country of location of & \\
headquarters, data "LOC" other than USA) listed on NYSE, ARCA, and NASDAQ as & 155 \\
ADRs or ordinary shares for the fiscal year 2017 with "December" fiscal year end & \\
Less: missing EDGAR data & $(15)$ \\
Less: no segment disclosure & $(29)$ \\
Less: firms in utility (SIC 4900-4999) and financial (SIC 6000-6999) industry & $(3)$ \\
Less: missing returns and earnings data & $(18)$ \\
\hline Final sample & 90
\end{tabular}

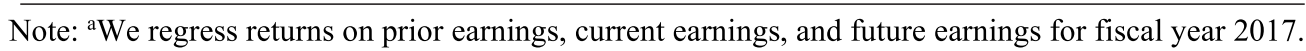
So, earnings data is required for 2016, 2017, and 2018.

TABLE 2: Descriptive Statistics

\begin{tabular}{lrrrrrr}
\hline Variables $^{\mathrm{a}}$ & $\mathrm{N}$ & Mean & Median & Minimum & Maximum & Std. error \\
\hline$R_{t}$ & 90 & -0.0159 & -0.0635 & -0.8261 & 1.5102 & 0.0403 \\
$E_{t-1}$ & 90 & -0.0589 & -0.0011 & -0.7783 & 0.2372 & 0.0202 \\
$E_{t}$ & 90 & -0.0134 & 0.0258 & -0.9345 & 0.6266 & 0.0229 \\
$E_{t+1}$ & 90 & -0.0404 & 0.0239 & -1.0811 & 0.8910 & 0.0284 \\
IFRS & 90 & 0.5667 & 1.0000 & 0.0000 & 1.0000 & 0.0525 \\
NUMSEG & 90 & 3.1222 & 2.0000 & 1.0000 & 10.0000 & 0.2634 \\
NUMWORDS & 90 & 625.8444 & 476.5000 & 11.000 & 2335.0000 & 53.9556 \\
WORDSPERSEG & 90 & 224.7605 & 187.0000 & 11.0000 & 929.5000 & 17.6899 \\
SDQTY & 90 & 5.1149 & 5.2311 & 2.3979 & 6.8346 & 0.0906 \\
NUMITEMS & 90 & 10.6222 & 7.0000 & 0.0000 & 44.0000 & 1.0870 \\
SDINDEX & 90 & 1.2699 & 1.2500 & 0.0000 & 2.0000 & 0.0442 \\
\hline
\end{tabular}

Notes: a See appendix A for variable definitions 


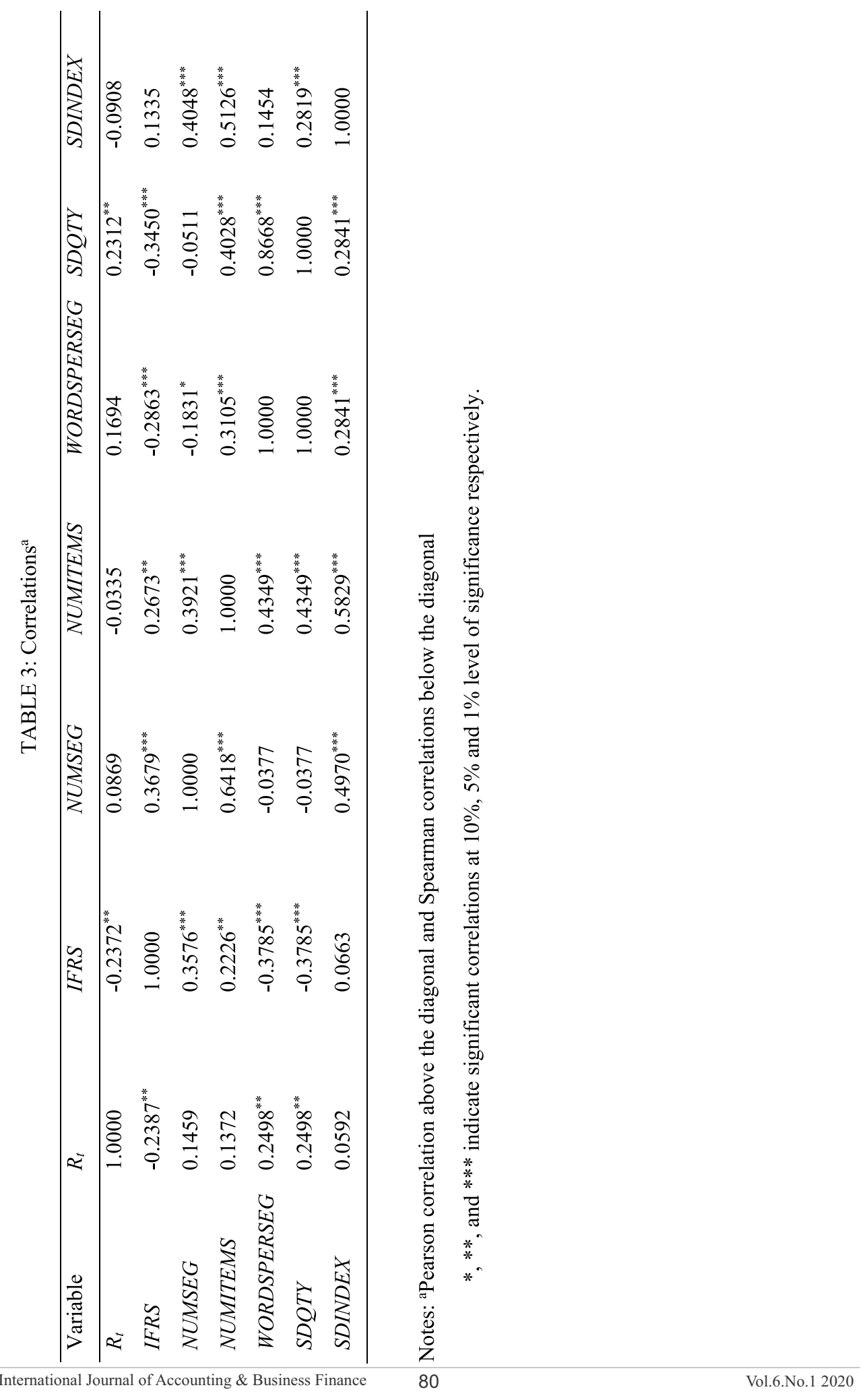


TABLE 4: Tests of Differences in Means (Medians) ${ }^{\mathrm{a}}$

\begin{tabular}{llllll}
\hline Variable & $\begin{array}{l}\text { U.S. GAAP } \\
\text { Mean }\end{array}$ & $\begin{array}{l}\text { IFRS } \\
\text { Mean }\end{array}$ & $\begin{array}{l}\text { Difference in } \\
\text { Means }\end{array}$ & t-value & $\begin{array}{l}\text { Kruskal-Wallis } \\
\text { test }- \text { Chi Square }\end{array}$ \\
\hline$R_{t}$ & 0.0873 & -0.0948 & 0.1821 & $2.21^{* *}$ & $5.0687^{* *}$ \\
NUMSEG & 2.0769 & 3.9216 & -1.8446 & $-3.98^{* * *}$ & $11.3789^{* * *}$ \\
WORDS & 543.5 & 688.8 & -145.3 & -1.41 & 0.6047 \\
WORDSPERSEG & 279.4 & 183.0 & 96.4101 & $2.81^{* * *}$ & $12.7484^{* * *}$ \\
SDQTY & 5.4520 & 4.8572 & 0.5948 & $3.59^{* * *}$ & $12.7484^{* * *}$ \\
NUMITEMS & 7.4872 & 13.0196 & -5.5324 & $-2.75^{* * *}$ & $4.41^{* *}$ \\
SDINDEX & 1.2062 & 1.3186 & -0.1124 & -1.29 & 0.3913
\end{tabular}

Notes: ${ }^{\mathbf{a}}$ These tests are for difference in means (medians) for firms using U.S. GAAP vs. IFRS for segment disclosure.

***, **, * indicate significant difference at $1 \%, 5 \%$, and $10 \%$ levels, respectively.

TABLE 5: Tests of Differences in Means (Medians) ${ }^{\mathrm{a}}$

\begin{tabular}{llllll}
\hline Variable & $\begin{array}{l}\text { Profitable Firms } \\
\text { Mean }(\mathrm{N}=56)\end{array}$ & $\begin{array}{l}\text { Loss Firms } \\
\text { Mean }(\mathrm{N}=34)\end{array}$ & $\begin{array}{l}\text { Difference in } \\
\text { Means }\end{array}$ & $\begin{array}{l}\mathrm{t} \text {-value } \\
\text { Kruskal-Wallis }\end{array}$ & $\begin{array}{l}\text { test }- \text { Chi Square } \\
\text { R }\end{array}$ \\
\hline NUMSEG & 0.0863 & -0.1841 & 0.2704 & $3.63^{* * *}$ & $13.9938^{* * *}$ \\
WORDS & 3.4643 & 2.5588 & 0.9055 & $1.79^{*}$ & $3.3602^{*}$ \\
WORDSPERSEG & 734.8 & 446.5 & 288.3 & $2.75^{* * *}$ & $8.8270^{* * *}$ \\
SDQTY & 262.8 & 162.2 & 100.6 & $3.18^{* * *}$ & $8.5329^{* * *}$ \\
NUMITEMS & 5.3188 & 4.7792 & 0.5396 & $2.95^{* * *}$ & $8.5329^{* * *}$ \\
SDINDEX & 11.7321 & 8.7941 & 2.9380 & 1.21 & $6.0288^{* *}$ \\
\hline
\end{tabular}

Notes: ${ }^{\text {a }}$ These tests are for difference in means (medians) for firms with positive vs. negative earnings during the fiscal year.

$* * *, * *, *$ indicate significant differences at $1 \%, 5 \%$, and $10 \%$ levels, respectively. 


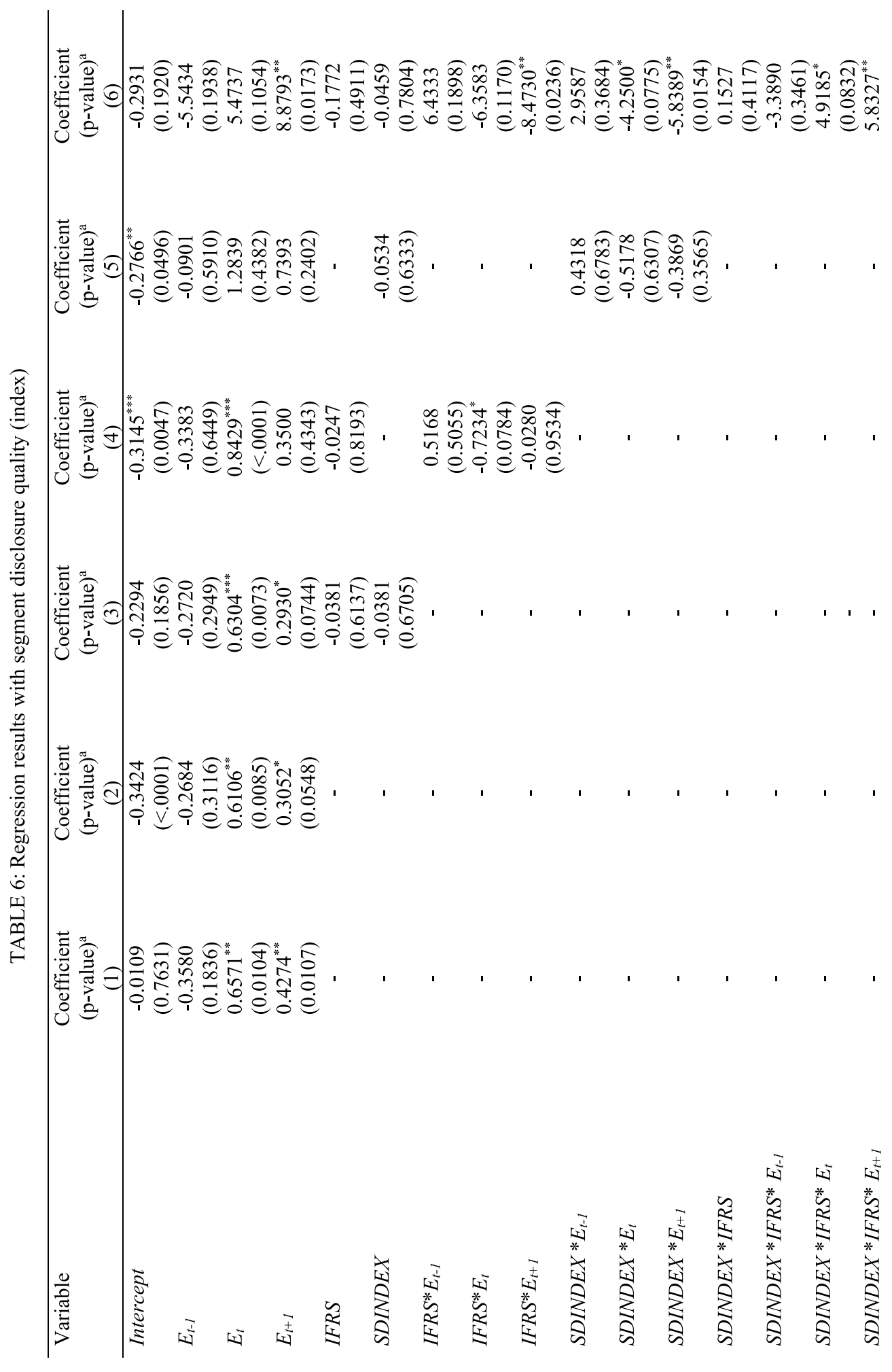




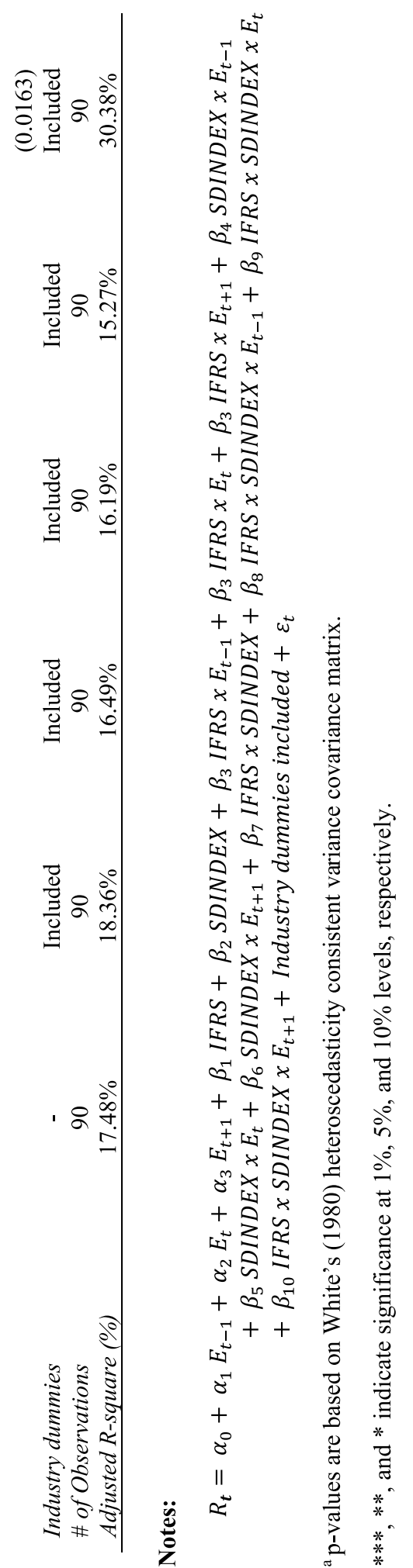

International Journal of Accounting \& Business Finance 
TABLE 7: Regression results with segment disclosure quantity

\begin{tabular}{|c|c|c|c|}
\hline Variable & $\begin{array}{l}\text { Coefficient } \\
(\mathrm{p} \text {-value })^{\mathrm{a}}\end{array}$ & $\begin{array}{l}\text { Coefficient } \\
\text { (p-value })^{\mathrm{a}}\end{array}$ & $\begin{array}{c}\text { Coefficient } \\
(\mathrm{p} \text {-value })^{\mathrm{a}}\end{array}$ \\
\hline \multirow[t]{2}{*}{ Intercept } & $-0.5449^{* *}$ & $-0.3145^{* * *}$ & $-1.0670^{* *}$ \\
\hline & $(0.0255)$ & $(0.0047)$ & $(0.0330)$ \\
\hline \multirow[t]{2}{*}{$E_{t-1}$} & -0.2986 & -0.3383 & $-33.2314^{* * *}$ \\
\hline & $(0.2134)$ & $(0.6449)$ & $(0.0008)$ \\
\hline \multirow[t]{2}{*}{$E_{t}$} & $0.5822^{* * *}$ & $0.8429^{* * *}$ & $17.0800^{* *}$ \\
\hline & $(0.0093)$ & $(<.0001)$ & $(0.0120)$ \\
\hline \multirow[t]{2}{*}{$E_{t+1}$} & $0.3209^{* *}$ & 0.3500 & $2.2694^{* * *}$ \\
\hline & $(0.0485)$ & $(0.4343)$ & $(0.0047)$ \\
\hline \multirow[t]{2}{*}{ IFRS } & -0.0229 & -0.0247 & 0.3305 \\
\hline & $(0.8042)$ & $(0.8193)$ & $(0.5254)$ \\
\hline \multirow[t]{2}{*}{$S D Q T Y$} & 0.0399 & - & 0.1159 \\
\hline & $(0.2823)$ & & $(0.2084)$ \\
\hline \multirow[t]{2}{*}{$I F R S^{*} E_{t-1}$} & - & 0.5168 & $37.4183^{* * *}$ \\
\hline & & $(0.5055)$ & $(0.0002)$ \\
\hline \multirow[t]{2}{*}{$I F R S^{*} E_{t}$} & - & $-0.7234^{*}$ & $-17.9613^{* *}$ \\
\hline & & $(0.0784)$ & $(0.0126)$ \\
\hline \multirow[t]{2}{*}{$I F R S^{*} E_{t+1}$} & - & -0.0280 & $-8.1360^{* * *}$ \\
\hline & & $(0.9534)$ & $(0.0055)$ \\
\hline \multirow[t]{2}{*}{$S D Q T Y * E_{t-1}$} & - & - & $5.6818^{* * *}$ \\
\hline & & & $(0.0009)$ \\
\hline \multirow[t]{2}{*}{$S D Q T Y * E_{t}$} & - & - & $-2.6633^{* *}$ \\
\hline & & & $(0.0177)$ \\
\hline \multirow[t]{2}{*}{$S D Q T Y * E_{t+1}$} & - & - & $-0.0059^{* * *}$ \\
\hline & & & $(0.0008)$ \\
\hline \multirow[t]{2}{*}{$S D Q T Y * I F R S$} & - & - & -0.0452 \\
\hline & & & $(0.6546)$ \\
\hline \multirow[t]{2}{*}{$S D Q T Y * I F R S^{*} E_{t-1}$} & - & - & $-6.5506^{* * *}$ \\
\hline & & & $(0.0003)$ \\
\hline \multirow[t]{2}{*}{$S D Q T Y * I F R S^{*} E_{t}$} & - & - & $2.9707^{* *}$ \\
\hline & & & $(0.0174)$ \\
\hline \multirow[t]{2}{*}{$S D Q T Y * I F R S^{*} E_{t+1}$} & - & - & $1.4609^{* * * *}$ \\
\hline & & & $(0.0063)$ \\
\hline Industry dummies & Included & Included & Included \\
\hline \# of Observations & 90 & 90 & 90 \\
\hline Adjusted R-square (\%) & $16.82 \%$ & $16.19 \%$ & $24.00 \%$ \\
\hline
\end{tabular}


TABLE 8: Additional Test

\begin{tabular}{|c|c|c|c|}
\hline Variable & $\begin{array}{l}\text { Coefficient } \\
(\mathrm{p} \text {-value })^{\mathrm{a}}\end{array}$ & 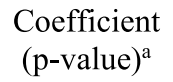 & $\begin{array}{l}\text { Coefficient } \\
{\text { (p-value })^{\mathrm{a}}}\end{array}$ \\
\hline \multirow[t]{2}{*}{ Intercept } & $-0.4532^{*}$ & -0.1822 & $-0.8334^{* * *}$ \\
\hline & $(0.0840)$ & $(0.5477$ & $(0.0008)$ \\
\hline \multirow[t]{2}{*}{$E_{t-1}$} & $-0.5140^{*}$ & -0.0916 & -4.6449 \\
\hline & $(0.0686)$ & $(0.8905)$ & $(0.2235)$ \\
\hline \multirow[t]{2}{*}{$E_{t}$} & 0.4288 & $0.7956^{* * *}$ & $7.1656^{* *}$ \\
\hline & $(0.1095)$ & $(0.0001)$ & $(0.0215)$ \\
\hline \multirow{2}{*}{$E_{t+1}$} & $0.2726^{*}$ & 0.1587 & $7.9113^{* * *}$ \\
\hline & $(0.0626)$ & $(0.6883)$ & $(0.0099)$ \\
\hline \multirow[t]{2}{*}{$I F R S$} & - & $-0.1769^{*}$ & $-0.5168^{* *}$ \\
\hline & & $(0.1000)$ & $(0.0214)$ \\
\hline \multirow[t]{2}{*}{$S D Q T Y$} & - & -0.1129 & -0.1438 \\
\hline & & $(0.3348)$ & $(0.3290)$ \\
\hline \multirow[t]{2}{*}{$\operatorname{IFRS^{*}} E_{t-1}$} & - & -0.2039 & -0.4492 \\
\hline & & $(0.7607)$ & $(0.9211)$ \\
\hline \multirow{2}{*}{$I F R S^{*} E_{t}$} & - & $-0.7509^{* *}$ & -5.6465 \\
\hline & & $(0.0381)$ & $(0.1163)$ \\
\hline \multirow[t]{2}{*}{$\operatorname{IFR} S^{*} E_{t+1}$} & - & 0.1306 & $-6.8032^{* *}$ \\
\hline & & $(0.7622)$ & $(0.0281)$ \\
\hline \multirow{2}{*}{$S D I N D E X^{*} E_{t-1}$} & - & - & 2.1478 \\
\hline & & & $(0.4822)$ \\
\hline \multirow{2}{*}{$S D I N D E X^{*} E_{t}$} & - & - & $-5.6545^{* *}$ \\
\hline & & & $(0.0168)$ \\
\hline \multirow[t]{2}{*}{$S D I N D E X^{*} E_{t+1}$} & - & - & $-5.3856^{* * *}$ \\
\hline & & & $(0.0088)$ \\
\hline \multirow[t]{2}{*}{$S D I N D E X * I F R S$} & - & - & $0.3501^{* *}$ \\
\hline & & & $(0.0335)$ \\
\hline \multirow[t]{2}{*}{$S D I N D E X^{*} I F R S^{*} E_{t-1}$} & - & - & 0.9233 \\
\hline & & & $(0.7897)$ \\
\hline \multirow[t]{2}{*}{$S D I N D E X^{*} I F R S^{*} E t$} & - & - & $4.7091^{*}$ \\
\hline & & & $(0.0772)$ \\
\hline \multirow[t]{2}{*}{$S D I N D E X^{*} I F R S^{*} E_{t+1}$} & - & - & $4.9376^{* *}$ \\
\hline & & & $(0.0173)$ \\
\hline \multirow[t]{2}{*}{$S I Z E$} & -0.0039 & -0.0054 & $0.0453^{* *}$ \\
\hline & $(0.8302)$ & $(0.7494)$ & $(0.0171)$ \\
\hline \multirow[t]{2}{*}{$M K T 2 B O O K$} & 0.0727 & 0.0520 & $0.0907^{* *}$ \\
\hline & $(0.1297)$ & $(0.2474)$ & $(0.0192)$ \\
\hline \multirow[t]{2}{*}{ LOSS } & -0.1007 & -0.1167 & -0.0899 \\
\hline & $(0.3034)$ & $(0.2171)$ & $(0.2140)$ \\
\hline \multirow[t]{2}{*}{ BIGNAUDITOR } & 0.1202 & 0.2052 & 0.0589 \\
\hline & $(0.4471)$ & $(0.1681)$ & $(0.6580)$ \\
\hline Industry dummies & Included & Included & Included \\
\hline \# of Observations & 85 & 85 & 85 \\
\hline Adjusted R-square (\%) & $15.01 \%$ & $13.63 \%$ & $44.09 \%$ \\
\hline
\end{tabular}

Notes: $R_{t}=\alpha_{0}+\alpha_{1} E_{t-1}+\alpha_{2} E_{t}+\alpha_{3} E_{t+1}+\beta_{1} I F R S+\beta_{2} S D I N D E X+\beta_{3} I F R S x E_{t-1}+\beta_{3} I F R S x E_{t}+$ $\beta_{3}$ IFRS $x E_{t+1}+\beta_{4}$ SDINDEX $x E_{t-1}+\beta_{5}$ SDINDEX $x E_{t}+\beta_{6}$ SDINDEX $x E_{t+1}+\beta_{7}$ IFRS $x$ SDINDEX + $\beta_{8}$ IFRS $\times$ SDINDEX $x E_{t-1}+\beta_{9}$ IFRS $\times$ SDINDEX $x E_{t}+\beta_{10}$ IFRS $x$ SDINDEX $x E_{t+1}+$ CONTROLS + Industry dummies included $+\varepsilon_{t}$

${ }^{a}$ p-values are based on White's (1980) heteroscedasticity consistent variance covariance matrix.

$* * *, * *$, and $*$ indicate significance at $1 \%, 5 \%$, and $10 \%$ levels, respectively.

International Journal of Accounting \& Business Finance 85 


\begin{tabular}{|c|c|}
\hline Variable & Definition \\
\hline BIGNAUDITOR & $\begin{array}{l}\text { is a dummy variable with value }=1 \text { if independent auditor of the sample company for the } \\
\text { fiscal year was a Big-Four auditor. }\end{array}$ \\
\hline$E_{i t}$ & $\begin{array}{l}\text { is the income before extraordinary items (Compustat annual item "IB") in year } t \text {, scaled } \\
\text { by market value of equity three months after year } t-1 \text { fiscal year-end; where market value } \\
\text { of equity = (closing price } \mathrm{x} \text { number of shares outstanding) is determined using CRSP } \\
\text { monthly stock data. }\end{array}$ \\
\hline$E_{i, t-1}$ & $\begin{array}{l}\text { is the income before extraordinary items in the year preceding year } t \text {, scaled by market } \\
\text { value of equity three months after year } t-1 \text { fiscal year-end. }\end{array}$ \\
\hline$E_{i, t+1}$ & $\begin{array}{l}\text { is the income before extraordinary items in the year following year } t \text {, scaled by market } \\
\text { value of equity three months after year } t-1 \text { fiscal year-end. }\end{array}$ \\
\hline INDUSTRY & is the two-digit SIC code of the company from Compustat. \\
\hline IFRS & $\begin{array}{l}\text { is a dummy variable with value }=1 \text { if firm used IFRS as the choice of accounting standards; } \\
\text { otherwise }=0 \text {. }\end{array}$ \\
\hline LOSS & $\begin{array}{l}\text { is a dummy variable with value }=1 \text { if firm had negative earnings during the fiscal year; } \\
\text { otherwise }=0 \text {. }\end{array}$ \\
\hline$M K T 2 B O O K$ & $\begin{array}{l}\text { is the ratio of market value of equity to book value of equity at the end of fiscal year; where } \\
\text { market value of equity is number of common shares outstanding (Compustat item } \\
\text { "CSHO") times the price of common stock at the end of fiscal year (Compustat item } \\
\text { "PRCC") and book value of equity is number of common shares outstanding (Compustat } \\
\text { item "CSHO") times book value of share at the end of the fiscal year (Compustat annual } \\
\text { item "BKVLPS"). }\end{array}$ \\
\hline NUMSEG & $\begin{array}{l}\text { is the number of operating segments reported in segment disclosure note (hand-collected } \\
\text { data). }\end{array}$ \\
\hline NUMWORDS & $\begin{array}{l}\text { is the simple word-count of segment disclosure information provided in the segment } \\
\text { disclosure note (hand-collected data) }\end{array}$ \\
\hline$R_{i t}$ & $\begin{array}{l}\text { is the buy-and-hold returns for the year } t \text {, measured over the12-month period starting three } \\
\text { months after year } t-1 \text { fiscal year-end using the monthly share price data adjusted for the } \\
\text { dividends. }\end{array}$ \\
\hline SDINDEX & $\begin{array}{l}\text { is segment disclosure index (a measure of segment disclosure quality) score based on } \\
\text { hand-collected data. See Appendix A. }\end{array}$ \\
\hline$S D Q T Y$ & is quantity of segment disclosure measured as the natural logarithm of WORDSPERSEG. \\
\hline$S I Z E$ & $\begin{array}{l}\text { is the natural logarithm of the market value of equity three months after the end of the } \\
\text { fiscal year } t-1\end{array}$ \\
\hline WORDSPERSEG & $\begin{array}{l}\text { is the number of words (NUMWORDS) divided by number of operating segments } \\
(N U M S E G)\end{array}$ \\
\hline
\end{tabular}




\section{APPENDIX A}

Our measure of segment disclosure quality, $S D I N D E X$, is based on material segment information disclosed by the sample firm. Specifically, we use following 8 questions about segment disclosure to develop our measure.

\begin{tabular}{|l|l|l|}
\hline & Question & Score \\
\hline 1. & Does the firm disclose primary segment assets? & Yes $=2 ;$ No $=0$ \\
\hline 2. & Does the firm disclose primary segment income (any income measure) $?$ & Yes $=2 ;$ No $=0$ \\
\hline 3. & Does the firm disclose primary segment liabilities? & Yes $=2 ;$ No $=0$ \\
\hline 4. & $\begin{array}{l}\text { Is the reconciliation of segment assets to enterprise's consolidated assets } \\
\text { shown? }\end{array}$ & Yes $=2 ;$ No $=0$ \\
\hline 5. & $\begin{array}{l}\text { Is the reconciliation of segment income to enterprise's consolidated income } \\
\text { shown? }\end{array}$ & Yes $=2 ;$ No $=0$ \\
\hline 6. & Is there any disclosure about major customer? & Yes $=2 ;$ No $=0$ \\
\hline 7. & From geographic disclosure, is profit/loss earned from the U.S. disclosed? & Yes $=2 ;$ No $=0$ \\
\hline 8. & From geographic disclosure, are assets located in the U.S. disclosed? & Yes $=2 ;$ No $=0$ \\
\hline & TOTAL & $=$ SDSCORE \\
\hline
\end{tabular}

SDINDEX $=$ SDSCORE $/ 8$

If a firm does not provide any geographic disclosure, then SDINDEX $=S D S C O R E$ / 6

If a firm does not provide any segment disclosure note then $S D I N D E X=0$ 